\title{
Juvenile gadoid habitat and ontogenetic shift observations using stereo-video baited cameras
}

\author{
Sophie A. M. Elliott ${ }^{1, *}$, William R. Turrell ${ }^{2}$, Michael R. Heath ${ }^{3}$, David M. Bailey ${ }^{1}$ \\ ${ }^{1}$ Institute of Biodiversity, Animal Health and Comparative Medicine, University of Glasgow, Glasgow G12 8QQ, UK \\ ${ }^{2}$ Marine Scotland Science, Marine Laboratory, Aberdeen AB11 9DB, UK \\ ${ }^{3}$ Department of Mathematics and Statistics, University of Strathclyde, Glasgow G1 1XQ, UK
}

\begin{abstract}
The protection of species requires an understanding of their habitat requirements and how habitat characteristics affect their distribution, survival and growth. This need is especially important in areas where anthropogenic pressures can not only have a significant direct impact on the survival of the species but also damage their habitat. The Firth of Clyde in southwestern Scotland was an important commercial fishing area for a variety of demersal fish species up until 1973. However, stocks rapidly declined thereafter and the catch of targeted species ceased in 2005, despite fisheries measures put in place to aid recovery. Changes in the availability and quality of fish habitat are possible explanations for this lack of recovery. Here, we report on stereo baited remote underwater video surveys in the Firth of Clyde between June and September in 2013 and 2014 to determine the habitat of juvenile Atlantic cod Gadus morhua, haddock Melanogrammus aeglefinus and whiting Merlangius merlangus. Habitat predictor variables explored included substratum type, depth, wave fetch, and epibenthic and demersal fauna diversity. G. morhua were most abundant in shallow, sheltered areas composed of gravel-pebble containing maerl. M. aeglefinus and M. merlangus predominated over deeper sand and mud. Ontogenetic shifts in all 3 species were also observed. Relative abundances of G. morhua and $M$. merlangus were positively related to the diversity of epibenthic and demersal fauna. Our results indicate that spatial conservation measures to benefit demersal fish should be advised by patterns of epibenthic and demersal fauna diversity as well as physical substratum types.
\end{abstract}

KEY WORDS: Nursery · Habitat association · Ontogenetic shift · Gadoid · Diversity · Atlantic cod · Gadus morhua $\cdot$ Density dependence $\cdot$ Stereo-video camera

\section{INTRODUCTION}

With increasing pressures on marine ecosystems and little recovery being observed in commercially important fish, it is essential to understand the factors affecting their survival. Unfortunately, in many cases, the habitat requirements of commercially important stocks are often not well understood. Atlantic cod Gadus morhua, haddock Melanogrammus aeglefinus and whiting Merlangius merlangus are of considerable economic importance throughout the North Atlantic (Cote et al. 2003, Fernandes \& Cook 2013). However, stocks of all 3 species declined in the late

${ }^{*}$ Corresponding author: sophie_elliott@yahoo.com 20th century (Holmes et al. 2014, ICES 2016a,b,c). Efforts have been put in place to recover these stocks, but little progress has been observed in much of the west coast of the UK, and recruitment and spawning stock biomass remains relatively low in that area for all 3 species (Fernandes \& Cook 2013, ICES 2016a,b,c). This is especially the case in the Firth of Clyde (southwest Scotland), where the demersal fishery was predominant (Thurstan \& Roberts 2010, Heath \& Speirs 2012)

The recovery of commercial fish species depends not only on reductions in targeted fishing and bycatch but also on healthy recruitment of juvenile fish.

(C) The authors 2017. Open Access under Creative Commons by Attribution Licence. Use, distribution and reproduction are unrestricted. Authors and original publication must be credited. 
To facilitate recruitment, juveniles need access to adequate food resources and shelter to minimise natural mortality and maximise survival and growth (Beck et al. 2001, Elliott et al. 2016b). Few studies have looked at the quality of the seabed indicated by epibenthic and demersal fauna diversity (mobile epibenthic fauna and demersal fish species). Understanding juvenile gadoid habitat is particularly important given that settlement and post-settlement survival is thought to be the best means to understanding gadoid population regulation (Myers \& Cadigan 1993, Olsen \& Moland 2011, Laurel et al. 2016). Furthermore, many species undergo ontogenetic shifts and may require more complex management measures for protection (Fitzpatrick et al. 2012, Nagelkerken et al. 2013).

For clarification purposes, the understanding of habitat refers to the substrata (abiotic and biotic seabed characteristics), physicochemical and biological characteristics required by a species to survive during a particular stage in its ontogeny (Elliott et al. 2016b). An important habitat component is one which a change in its condition or availability may directly affect the species success (e.g. survival or growth) (Gibson 1994, Able 1999, Elliott et al. 2016b). Terms outlined within Elliott et al. (2016b) have been used to improve understanding of the relationship between juvenile gadoids and their habitats. Many studies that have looked at the habitat use of these gadoids have not considered biological characteristics, such as how other species may affect abundance observations (e.g. Tupper \& Boutilier 1995a, Bertelli \& Unsworth 2014, Seitz et al. 2014). This is most likely due to the difficulties of quantifying biological characteristics and interactions using traditional trawl survey methods (Lima \& Dill 1990, Able 1999).

Structurally rugose substrata, such as cobbles, kelp beds and seagrass, provide refuge from predators for juvenile G. morhua (Gotceitas \& Brown 1993, Gotceitas et al. 1995, Tupper \& Boutilier 1995a). However, if these substrata become saturated from increased juvenile gadoid abundance, juveniles may be forced into lower-quality areas where survival is likely to be lower (Morris 1989, 2003, Laurel et al. 2004). Equally, areas of higher biodiversity may provide increased food sources in addition to refuge (Sebens 1991, Gratwicke \& Speight 2005, Kovalenko et al. 2012). Few in situ studies have been undertaken to explore $M$. aeglefinus and $M$. merlangus substratum association.

The majority of fish distribution and abundance surveys around the UK, and more widely, have taken place through trawl and egg surveys (Vasconcelos et al. 2014) (e.g. Gibson et al. 1996, Wright et al. 2010, Bastrikin et al. 2014). Such methods provide little information on fine-scale substratum associations that may affect gadoid distribution (e.g. Gregory \& Anderson 1997, Gorman et al. 2009). Photogrammetric techniques can provide a useful means of collecting non-damaging and non-extractive data on fish, epibenthos and substrata (Harvey et al. 2007, Fitzpatrick et al. 2012, Elliott et al. 2016a). Data collection using imaging enables access to shallow and structurally rugose seabed types, and protected areas that would otherwise be inaccessible using trawl or seine netting methods (Cappo et al. 2006).

Stereo imaging systems are particularly advantageous as they enable accurate measurements to be made from stills or video (Harvey et al. 2002). Baited cameras are commonly presumed to be biased towards larger predators and scavengers (Lowry et al. 2012, Dunlop et al. 2015). However, comparisons between baited and unbaited cameras have shown higher relative abundances and species diversity in baited camera observations (Watson et al. 2005, Harvey et al. 2007, Bernard \& Götz 2012). Stereo baited remote underwater video (SBRUV) surveys may be part of the solution to the survey and monitoring requirements of spatial management in the UK.

The aims of this study were to identify the environmental variables (including 5 seabed types, epibenthic and demersal fauna diversity through ShannonWiener entropy, depth and wave fetch) that juvenile gadoids are associated with, and to describe their habitat using SBRUV deployments. By understanding the habitat variables affecting the distribution and growth of juvenile gadoids, multi-purpose protection measures can be proposed to protect not only vulnerable benthos of conservation importance but also commercially valuable gadoids.

\section{MATERIALS AND METHODS}

\section{Study area}

Data were collected within the South Arran Nature Conservation Marine Protected Area (NCMPA) at depths of 4.0-47.2 m (Fig. 1). The NCMPA was designated in 2014 for its seagrass and maerl beds (coralline red algae Phymatolithon calcareum) in addition to burrowed mud, kelp and seaweed communities and epibenthic fauna (www.snh.gov.uk/ protecting-scotlands-nature/protected-areas/nationaldesignations/mpas), and encompasses an area of $250 \mathrm{~km}^{2}$. Data were collected between June and Sep- 


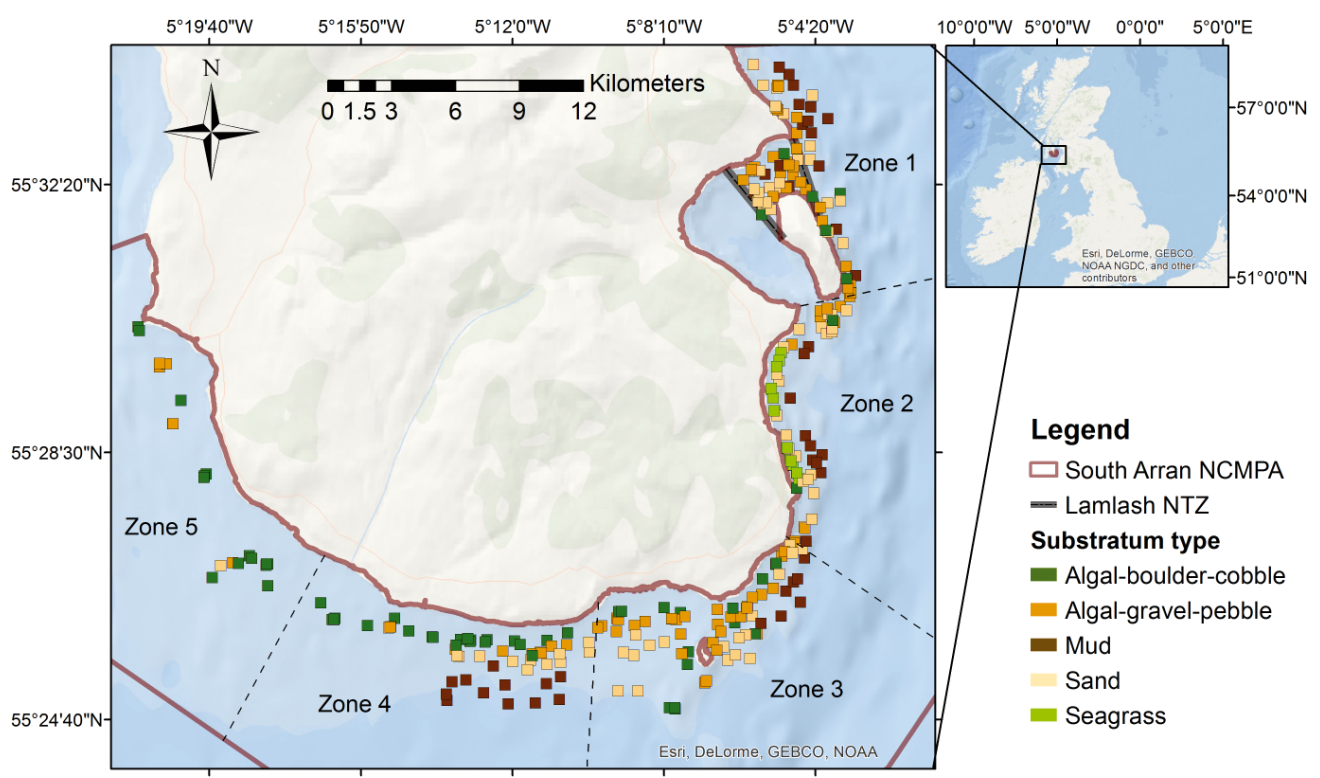

Fig. 1. Stereo baited remote underwater video (SBRUV) deployment locations within South Arran Nature Conservation Marine Protected Area (NCMPA) and Lamlash no-take zone (NTZ) over the course of 2013 and 2014. Different coloured squares represent the different substratum types observed

tember 2013 and 2014, but took place before management measures were implemented. Within the NCMPA, the Lamlash Bay no-take zone (designated in 2008) covers an area of $2.67 \mathrm{~km}^{2}$, where all commercial and recreational fishing is prohibited within its boundaries (Thurstan \& Roberts 2010).

\section{Data collection}

In the sampling design, the NCMPA was divided into 5 zones, with samples collected within each zone over the period of data collection to facilitate replication. These zones differed in wave fetch (Burrows et al. 2008) and substratum type (following the collation of existing information from locals and broad-scale predicted seabed maps). Stratified random sampling location points within each zone were generated using Geospatial Modelling Environment software (version 10.1, http://spatialecology.com/). Deployment locations varied slightly between years due to logistical reasons (during field season 2013 a 6.5 m RIB was used; during field season 2014 a slower-speed, larger $10.8 \mathrm{~m}$ research vessel was used). For 2013, 74 deployments were conducted between 5 June and 29 September. However, only data collected after 15 July were used due to the late arrival of gadoids. During 2014, 186 deployments were conducted from 30 June to 18 September in 4 time periods (for boat time efficiency) during the course of the summer.
Three baited camera systems were used, each consisting of a pair of high-definition Canon (HF G25) video cameras in waterproof housings (SeaGIS, www.seagis.com.au/). The cameras were mounted on a 57 -cm-high custom made steel frame (Fig. 2), angled at an $\sim 15^{\circ}$ oblique view to have a partial view of the seabed and an inward angle of approximately $\sim 8^{\circ}$ with a basal separation of $58 \mathrm{~cm}$. Each camera was set to manual mode with the focal length set to

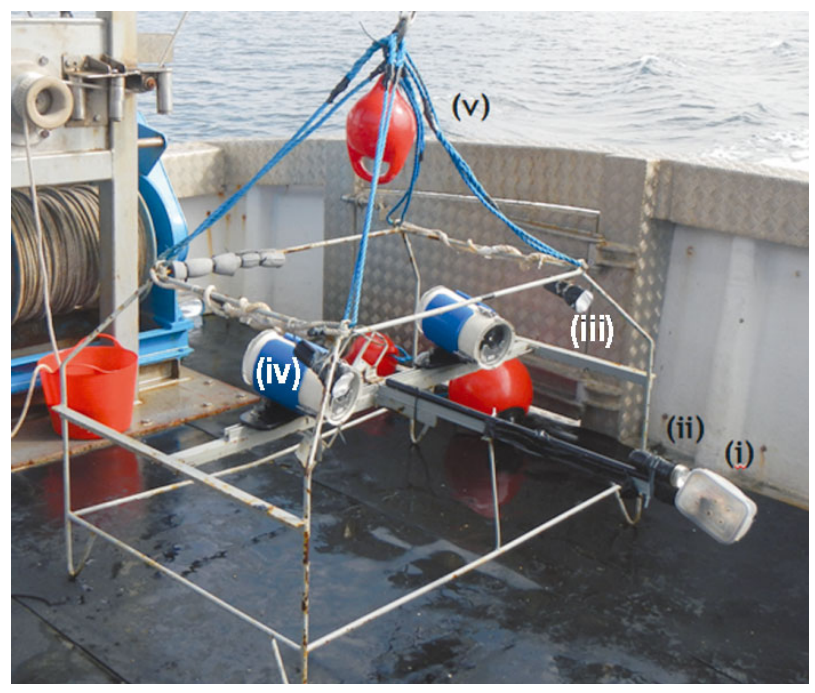

Fig. 2. Stereo baited remote underwater video system showing (i) bait box, (ii) strobe to synchronise cameras, (iii) torches, (iv) waterproof housing containing video cameras and (v) float and ropes to deploy the frame to the seabed from the vessel 
infinity $(\infty)$. Two underwater, LED W38VR Archonlight (1400 lumen) torches were mounted on the frame, facing at an angle to the middle of the stereocamera field of view. A flashing strobe and bait box was attached on a 91-cm-long bait arm situated in front of the camera. The strobe was used to synchronise the stereo-video images. Bait consisted of $500 \mathrm{~g}$ of cut Atlantic mackerel Scomber scombrus. The SBRUV frame was tethered to a rope for deployment and retrieval.

The system was set up in a similar way to the prototype described in Harvey \& Shortis $(1995,1998)$. However, our system was optimised for smaller-bodied $(<50 \mathrm{~cm})$ fish in seawater with a visibility of $<6 \mathrm{~m}$ distance by bringing the cameras closer together. The maximum depth and width of the field of view at which gadoids could be measured was $4 \mathrm{~m} \times 2 \mathrm{~m}$. Prior to and over the course of field data collection, the mounted cameras were calibrated within a controlled environment using the methods outlined in Harvey \& Shortis (1998) and CAL software manual (version 2.11, www.seagis.com.au/event.html).

Camera systems were deployed for a minimum of 55 min on the seabed. This deployment length provided the best compromise between sufficient bait soak time for species accumulation, as tested by Unsworth et al. (2014), and the need to bait and redeploy each camera multiple times on each sampling day. To minimise the possibility of deployments affecting each other, SBRUV deployments on the same day were a minimum distance of $500 \mathrm{~m}$ apart to minimise the possibility of juveniles swimming between SBRUV deployments. Samples were collected between 09:00 and 15:00 h (GMT), so that all deployments would be a minimum of $3 \mathrm{~h}$ after sunrise and $3 \mathrm{~h}$ before sunset to avoid crepuscular variation in fauna behaviour (e.g. Keats \& Steele 1992, Bertelli \& Unsworth 2014).

\section{Video analysis}

Each deployment was analysed using Event Measure software (version 3.42, www.seagis.com.au/event. $\mathrm{html}$ ) and a sample of 48 deployments were analysed by 2 separate observers to check for observer bias. All epibenthic and demersal fauna identified were quantified to the lowest taxonomic level possible. The maximum number of individuals of the same species appearing in a frame at the same time $(\mathrm{MaxN})$ was used as a measure of relative abundance (Priede et al. 1994, Watson et al. 2005, Cappo et al. 2006). MaxN avoids repeat counts of individuals reentering the field of view (Priede et al. 1994, Watson et al. 2005).

For gadoid length measurements, each individual observed had to be visible in both cameras. Fish fork length measurements were taken at one time point per deployment, when the maximum number of measurable fish was present. All length measurements with a root mean square (RMS) error $>2 \mathrm{~cm}$ and a precision of length measurement $>0.5 \mathrm{~cm}$ were removed from the analysis.

To undertake seabed-type categorisation, still images were extracted from the video recordings. Coral Point Count (CPC) analysis (version 4.1; Kohler \& Gill 2006) was used to record sediment and macrophyte type from the still images taken of the seabed. Two divisions of the Wentworth grain scale (Wentworth 1922) were used to classify sediment type (Connor et al. 2004). A total of $66(11 \times 6)$ randomly stratified points were overlaid on the image during CPC analysis following similar protocols used by Deter et al. (2012). Using the outputs from the CPC analysis, substratum categories were assigned based on the most dominant substrata occurring within each sample (Table 1), as per Elliott et al. (2016a). Substratum categories consisted of algal-boulder-cobble (ABC),

Table 1. Substratum type characterisation

\begin{tabular}{|c|c|c|c|}
\hline Substratum type & Sediment composition & Particle size $(\mathrm{cm})$ & Macrophyte type and density \\
\hline Algal-boulder-cobble (ABC) & Boulders and cobbles & $>6.4$ & $\begin{array}{l}\text { Sediment covered in a mixture of kelp } \\
\text { and red algae ( }>60 \%) \text {, e.g. Laminaria spp. } \\
\text { and Ceramium spp. }\end{array}$ \\
\hline Algal-gravel-pebble (AGP) & $\begin{array}{l}\text { Gravel (stone, shell and } \\
\text { maerl Phymatolithon } \\
\text { calcareum) and pebble }\end{array}$ & $\sim 1.6-6.4$ & Between 20 and $50 \%$ cover by algae \\
\hline Seagrass & Sandy sediment & $\sim 0.1-0.4$ & Presence of seagrass Zostera marina \\
\hline Sand & Sandy sediment & $\sim 0.1-0.4$ & Absence of macrophytes \\
\hline Mud & $\begin{array}{l}\text { Mud and sandy mud } \\
\text { sediment grain size }\end{array}$ & $<0.1$ & Absence of algae \\
\hline
\end{tabular}


algal-gravel-pebble (AGP), seagrass Zostera marina, sand and mud (Table 1). Maerl was not treated separately as a result of its gravel-pebble-sized form around South Arran. Furthermore, impacted maerl has been demonstrated to be more similar to gravel than live maerl (Kamenos et al. 2003).

\section{Data analysis}

Permutational multivariate analysis of variance (PERMANOVA) was performed in PERMANOVA 6 software (Anderson et al. 2008) to investigate community composition differences in epibenthic and demersal fauna within and between substratum types. To explore community composition differences, the MaxN of epibenthic and demersal fauna were fourthroot transformed, to reduce the influence of dominant species (Clarke \& Green 1988). Prior to applying PERMANOVA, a Bray-Curtis similarity coefficient was performed. Posterior pair-wise tests were used to compare the difference between substratum categories. PERMANOVA was run with 9999 permutations and results were considered significant at $\mathrm{p}($ perm $)<0.01$. Non-metric multi-dimensional scaling (nMDS) plots were used to visualise differences in epibenthic and demersal fauna between substratum types. nMDS plots provide a stress values that increase with reduced dimensionality or ordination (Clarke \& Warwick 2001). Similarity percentages (SIMPER) analysis was used to determine species that contributed most to the dissimilarity between the different substratum types (Clarke \& Warwick 2001).

To identify gadoid habitat variables, the abiotic variables explored included substratum type (categorical, 5 levels), depth (m), distance from coast (m), wave fetch $(\mathrm{km})$ and year (categorical, 2 levels). Year was included in the model due to slight differences in sampling between years. The effect of epibenthic and demersal fauna MaxN was explored by ShannonWiener entropy (Jost 2010). To facilitate comparability between units, continuous explanatory variables were standardised by dividing the mean by the standard deviation prior to statistical analysis. Random effects used included the effect of the zones and grouped days of data collection where significant. Depth data were obtained from vessel echosounders. Distance from coast was calculated using the GPS fix made at the time of deployment and ArcGIS version 10.1 (EDINA digimap). Wave fetch values for a $200 \mathrm{~m}$ coastline grid (www.sams.ac.uk/michael-burrows/ downloads) were used as described in Burrows et al. (2008).
Univariate statistical analysis was performed with the software R (version 3.2.1; R Core Team; www.rproject.org). Data exploration followed recommendations from Zuur et al. (2010). Homogeneity and potential outliers were analysed with boxplots. Variance inflation factor analysis and Spearman's rank correlations were used to test for collinearity. Temporal autocorrelation was accounted for by including year in the statistical model and day of collection as a random effect. Spatial independence was evaluated with variograms using R package geoR (http://CRAN.R-project.org/package=geoR). No spatial autocorrelation was observed. The model of best fit for all count data was a negative binomial distribution to account for over dispersion, using R package glmmADMD (http:// glmmadmb.r-forge.r-project.org/). Backwards stepwise model selection was implemented (Bolker et al. 2009, Zuur et al. 2010), looking for potential interactions. Model selection and significance was tested using a log-likelihood ratio test. Pearson's residuals were compared between models, fitting a model with the highest level of heteroscedasticity. Tukey tests using R package multcomp (Hothorn et al. 2008) were performed to test for differences between categorical variables.

Eq. (1) provides the model structure used to explore juvenile gadoid habitat:

$$
\log \left(Y_{i}\right)=\beta_{0}+\beta_{1}, X_{i j}+\beta_{2}, X_{i}+\beta_{3}, X_{i} \ldots+z_{i j}+t_{i j}
$$

where $Y_{i}$ is the gadoid MaxN, $\beta$ are the coefficients, $X$ are the explanatory variables, $z_{i j}$ and $t_{i j}$ are the random effects (zone and day of collection, respectively), $i$ represents continuous-variable samples and ij represents categorical-variable samples.

Differences in substratum association between years was analysed via Eq. (2):

$$
\log \left(Y_{i}\right)=\beta_{0}+\beta_{1}, S_{i j} * \beta_{2}, Y_{i j}+z_{i j}
$$

where $S_{i j}$ is the is substratum type and $Y_{i j}$ is the year.

The habitat variables described above and day of the year were used to explore for any size-related differences in age- 0 gadoids, enabling inferences on the quality of the habitat to be made (Gibson 1994, Able 1999, Elliott et al. 2016b). To reduce the likelihood of including age-1 gadoids, all individuals larger than $15 \mathrm{~cm}$ were removed from the analysis following DAtabase of TRAwl Surveys (DATRAS) ALK (product for standard species only) quarter 4 (October-December) data for the Clyde area (www. datras.com). Linear mixed models were employed using the R package nlme (http://CRAN.R-project. org/package=nlme) for length measurements:

$$
Y_{i}=\beta_{0}+\beta_{1}, D_{i / j}+\beta_{1}, X_{i}
$$


where $Y_{i}$ is the gadoid fork length and $D$ is day of the year.

To investigate whether the ability to identify and measure gadoids decreased with increasing depth (and therefore possibly reduced light), an ANOVA test was used to confirm that the ability to identify and measure gadoids did not decrease with depth.

\section{RESULTS}

\section{Community composition substratum differences}

Over the course of data collection, a total of 6186 epibenthic and demersal individuals from 65 species were recorded from the SBRUV deployments. Significant differences in community composition between substratum types were observed (pseudo- $F=6.53$, $\mathrm{p}($ perm $)<0.0001)$. Table 2 shows significant pair-wise test differences between substratum types and SIMPER percentage dissimilarity between substratum types and species. The nMDS plot had a stress value of 0.21 (relatively low), illustrating differences between the substratum types with some overlap (Fig. 3).

\section{Gadus morhua habitat}

An increase in MaxN was observed with increasing Shannon-Wiener entropy. A decrease in MaxN was observed with increasing depth and wave fetch (Fig. 4). Fewer G. morhua were observed in 2014 than 2013 (Table 3). Since no G. morhua were ob-

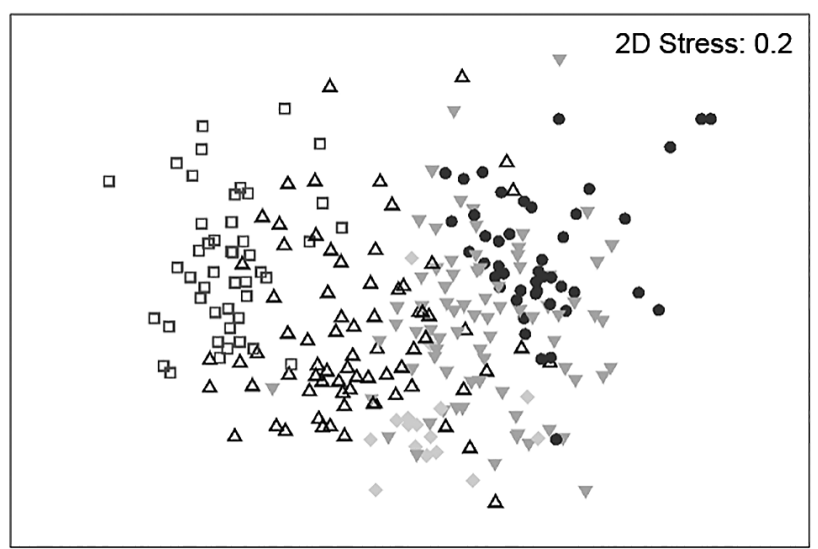

Fig. 3. Non-metric multi-dimensional scaling ordination plot (fourth-root transformation with Bray Curtis resemblance matrix) of mobile fauna observed over the different substratum types $(\square$, algal-boulder-cobble; $\Delta$, algal-gravel-pebble; $\bullet$, seagrass; $\boldsymbol{\nabla}$, sand; $\bullet$, mud). Significant effects of substratum type on assemblage structure were observed (PERMANOVA, $\mathrm{p}<0.001)$

served over mud, this category was removed from the analysis to improve logistic model convergence. The highest MaxN was observed over AGP and the mean average MaxN was observed over sand $(1=$ $-310.99, \mathrm{df}=10, \theta=1.09, \mathrm{p}<0.001$; Figs. 4 \& 5). A significant difference in MaxN across substrata and year was observed. During both years, higher $G$. morhua MaxN was observed over AGP than other substrata. In addition, mean MaxN observed over AGP remained relatively constant, whereas it decreased over other substrata $(\mathrm{l}=-331.36, \mathrm{df}=10, \theta=$ 1.09, p < 0.001; Fig. 5).

Table 2. Pairwise tests and percentage dissimilarity in epibenthic and demersal fauna assemblage composition between substratum type. PERMANOVA was run 9999 times and results were considered significant at p(perm) < 0.01. AGP, algalgravel-pebble; $\mathrm{ABC}$, algal-boulder-cobble

\begin{tabular}{|c|c|c|c|c|c|}
\hline Substratum types & $t$ statistic & $\mathrm{p}($ perm $)$ & $\begin{array}{l}\text { Unique } \\
\text { perms }\end{array}$ & $\begin{array}{l}\text { Dissimi- } \\
\text { larity }(\%)\end{array}$ & Top 3 species causing dissimilarity \\
\hline AGP, sand & 2.16 & 0.05 & 9945 & 79 & $\begin{array}{l}\text { Gadus morhua, Melanogrammus aeglefinus, flatfish } \\
\text { Pleuronectiformes }\end{array}$ \\
\hline AGP, seagrass & 5.10 & 0.01 & 9962 & 73 & Pleuronectiformes, shore crab Carcinus maenas, G. morhua \\
\hline $\mathrm{AGP}, \mathrm{ABC}$ & 4.24 & 0.00 & 9933 & 77 & $\begin{array}{l}\text { Goldsinny Ctenolabrus rupestris, G. morhua, two-spotted } \\
\text { goby Gobiusculus flavescens }\end{array}$ \\
\hline AGP, mud & 3.51 & 0.05 & 9868 & 82 & $\begin{array}{l}\text { G. morhua, rugose squat lobster Munida rugosa, } \\
\text { Merlangius merlangus }\end{array}$ \\
\hline Sand, $\mathrm{ABC}$ & 4.57 & 0.00 & 9949 & 90 & $\begin{array}{l}\text { C. rupestris, } M . \text { aeglefinus, harbour crab Liocarcinus } \\
\text { depurator }\end{array}$ \\
\hline Sand, seagrass & 2.42 & 0.01 & 9966 & 68 & C. maenas, $M$. aeglefinus, G. morhua \\
\hline Sand, mud & 3.55 & 0.05 & 9852 & 67 & M. rugosa, $M$. merlangus, $M$. aeglefinus \\
\hline$A B C$, seagrass & 6.43 & 0.00 & 9939 & 87 & C. rupestris, Pleuronectiformes, L. depurator \\
\hline $\mathrm{ABC}$, mud & 4.77 & 0.00 & 9849 & 95 & C. rupestris, $M$. rugosa, $M$. merlangus \\
\hline Seagrass, mud & 3.29 & 0.01 & 4378 & 78 & M. rugosa, C. maenas, G. morhua \\
\hline
\end{tabular}



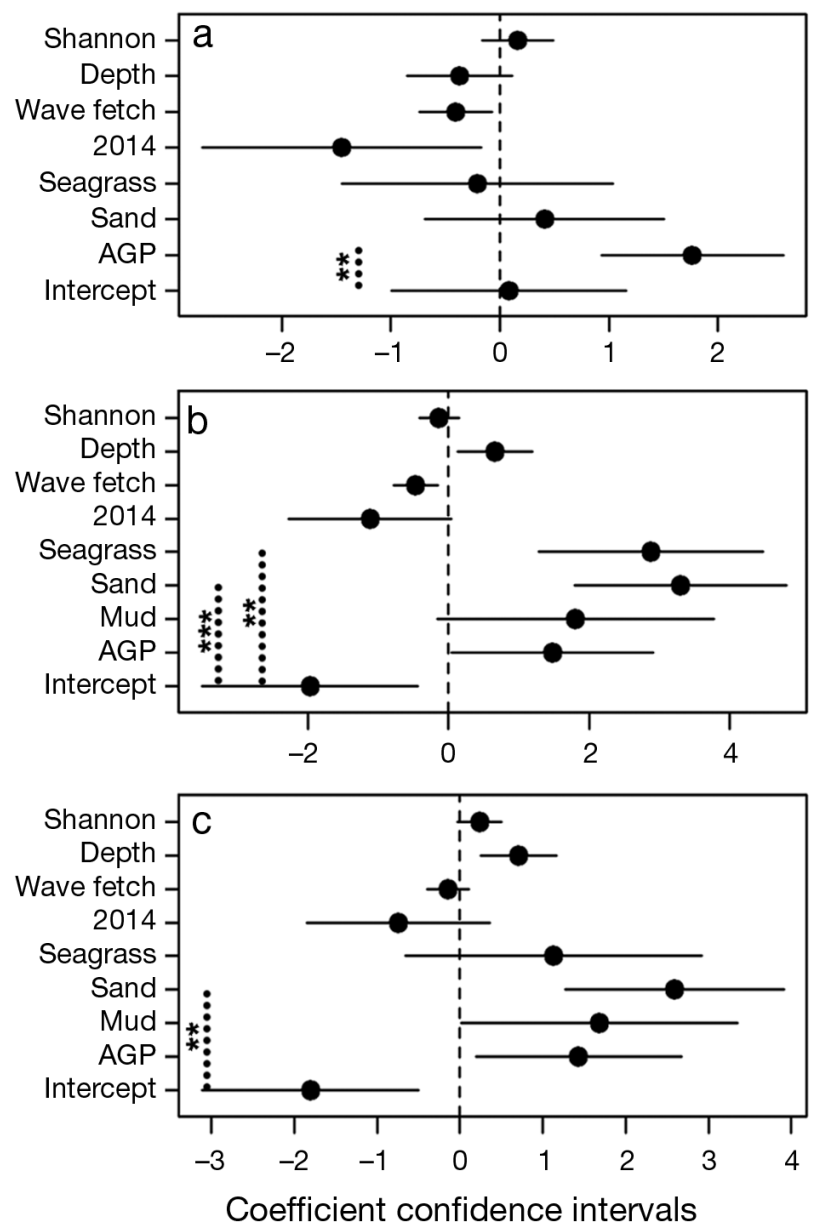

Fig. 4. Coefficient plot for model of best fit for (a) Gadus morhua, (b) Melanogrammus aeglefinus and (c) Merlangius merlangus habitat variables. Lines are the $95 \%$ confidence intervals for each of the explanatory variables. The continuous vertical dashed line is the reference line enabling us to see which coefficients are significantly different from zero. The intercept represents algal-boulder-cobble and year 1 (2013) of data collection, AGP refers to algal-gravel-pebble. Dotted vertical lines with ${ }^{*}$ refer to Tukey test p-value significance between substrata: $\left.{ }^{* *} \mathrm{p}<0.01,{ }^{* * *} \mathrm{p}<0.001\right)$
During field season 2013, an increase in length was observed, as well as an increase in length with Shannon-Wiener entropy $(l=-248.49$, df = 7, $p<0.001$; Table 4). Significantly larger G. morhua were observed over AGP $(7.5 \mathrm{~cm}, \mathrm{SE} \pm 0.03 \mathrm{~cm})$ than sand $(5.7 \mathrm{~cm}, \mathrm{SE} \pm 0.1 \mathrm{~cm})(\mathrm{p}<0.05$; Fig. 6$)$. During field season 2014, a significant increase in length was observed over the period of data collection (Table 4). Significantly larger G. morhua were observed over seagrass $(10.2 \mathrm{~cm}, \mathrm{SE} \pm 0.1 \mathrm{~cm})$ than AGP $(7.8 \mathrm{~cm}$, $\mathrm{SE} \pm 0.03 \mathrm{~cm})(\mathrm{l}=-188.33, \mathrm{df}=5, \mathrm{p}<0.05$; Fig. 6).

\section{Melanogrammus aeglefinus habitat}

An increase in $M$. aeglefinus MaxN was observed with increasing depth. A decrease in MaxN was observed with increasing wave fetch and Shannon entropy (Fig. 4). More individuals were observed in 2014 than 2013 (Table 3). The highest MaxN for $M$. aeglefinus was observed over the sand with lowest MaxN observed over ABC $(1=-279.92$, df $=11, \theta=$ 1.33, p < 0.001; Fig. 5).

Due to differences in data collection between years, it was not possible to undertake statistical analysis comparing $M$. aeglefinus MaxN between substratum type, since no data were collected in deeper water containing mud in year one. Over the course of both years, few individuals were observed in ABC and consistently greater numbers of $M$. aeglefinus were, however, observed over sand (Fig. 5).

A significant increase in length was observed over the course of data collection during $2013(1=-88.19$, $\mathrm{df}=3, \mathrm{p}<0.001$; Table 4). During field season 2014, a significant increase in length was observed over the course of data collection in addition to increasing length with depth and wave fetch $(l=-221.93$, $\mathrm{df}=7$, $\mathrm{p}<0.001$; Table 4).

Table 3. Juvenile gadoid MaxN summary results. Arrows represent an increase or decrease in gadoid MaxN

\begin{tabular}{|c|c|c|c|c|c|}
\hline Species & Year & $\begin{array}{c}\text { Total number } \\
\text { of individuals } \\
\text { measured at MaxN }\end{array}$ & $\begin{array}{c}\text { Mean } \\
\operatorname{MaxN} \pm S E\end{array}$ & $\begin{array}{l}\text { Habitat variable } \\
\text { effect for both } \\
2013 \text { and } 2014\end{array}$ & $\begin{array}{l}\text { Substratum significant } \\
\text { difference for both } \\
2013 \text { and } 2014\end{array}$ \\
\hline Gadus morhua & $\begin{array}{l}2013 \\
2014\end{array}$ & $\begin{array}{l}268 \\
182\end{array}$ & $\begin{array}{l}3.62 \pm 0.44 \\
1.31 \pm 0.38\end{array}$ & $\begin{array}{c}\text { Shannon } \uparrow \\
\text { Depth } \downarrow \\
\text { Wave fetch } \downarrow\end{array}$ & $\mathrm{AGP}-\mathrm{ABC}$ \\
\hline Melanogrammus aeglefinus & $\begin{array}{l}2013 \\
2014\end{array}$ & $\begin{array}{c}64 \\
190\end{array}$ & $\begin{array}{l}0.86 \pm 0.37 \\
1.03 \pm 0.15\end{array}$ & $\begin{array}{c}\text { Shannon } \downarrow \\
\text { Depth } \uparrow \\
\text { Wave fetch } \downarrow\end{array}$ & $\begin{array}{c}\text { Sand-ABC } \\
\text { Seagrass-ABC }\end{array}$ \\
\hline Merlangius merlangus & $\begin{array}{l}2013 \\
2014\end{array}$ & $\begin{array}{c}30 \\
192\end{array}$ & $\begin{array}{l}0.40 \pm 1.02 \\
1.05 \pm 2.18\end{array}$ & $\begin{array}{c}\text { Shannon } \uparrow \\
\text { Depth } \uparrow \\
\text { Wave fetch } \downarrow\end{array}$ & Sand-ABC \\
\hline
\end{tabular}



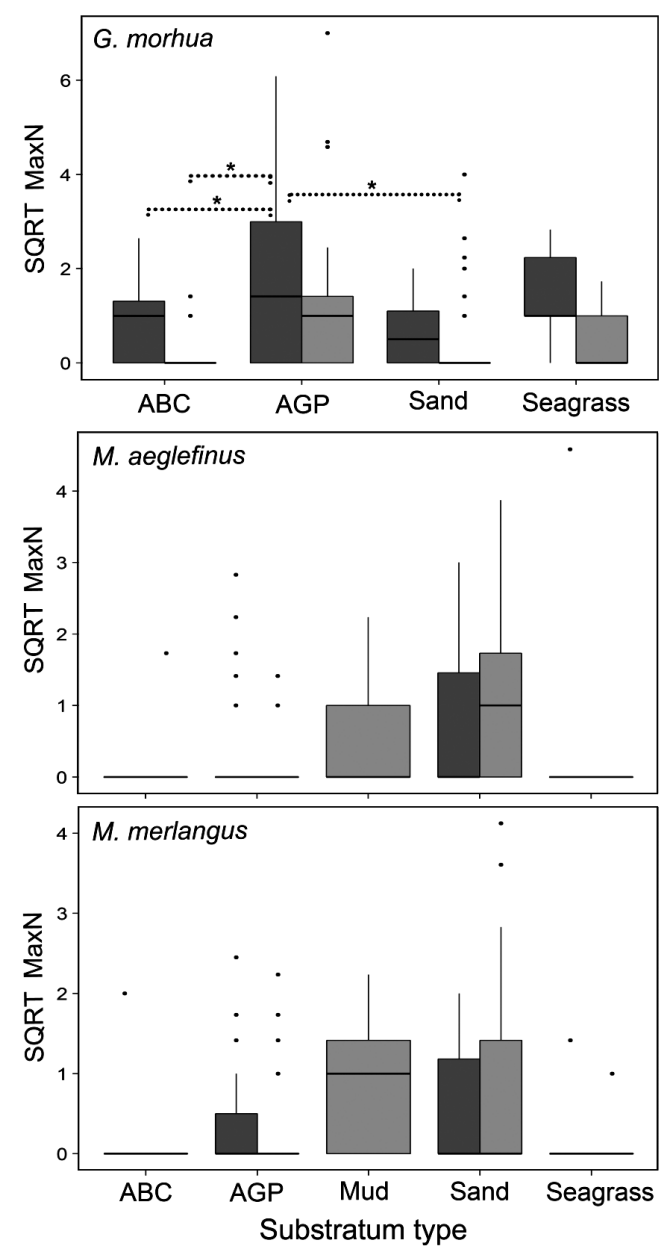

Fig. 5. Substratum association between data collection period 2013 (dark grey) and 2014 (light grey) for juvenile Gadus morhua, Melanogrammus aeglefinus and Merlangius merlangus observed within South Arran Nature Conservation Marine Protected Area. Boxplots: 25th and 75th percentiles of the total number of juvenile gadoids observed within the different substrata; upper and lower whiskers: 10th and 90th percentiles; thick horizontal line: median MaxN; solid dots: outliers. Dotted horizontal lines with ${ }^{*}$ refer to Tukey test $\mathrm{p}$-value significance between substrata $(\mathrm{p}<0.05)$. ABC, algalboulder-cobble; AGP, algal-gravel-pebble

\section{Merlangius merlangus habitat}

An increase in MaxN was observed with increasing Shannon-Wiener entropy and depth and a decrease in MaxN was observed with increasing wave fetch (Fig. 4). Fewer individuals were observed in 2013 (Table 3). The highest MaxN for M. merlangus was observed over sand with the lowest MaxN observed over $\mathrm{ABC}(\mathrm{l}=-273.64, \mathrm{df}=11, \theta=1.17, \mathrm{p}<$ 0.001; Figs. 4 \& 5). More M. merlangus was observed over sand substrata than the other substrata over the 2 years of data collection (Fig. 5).

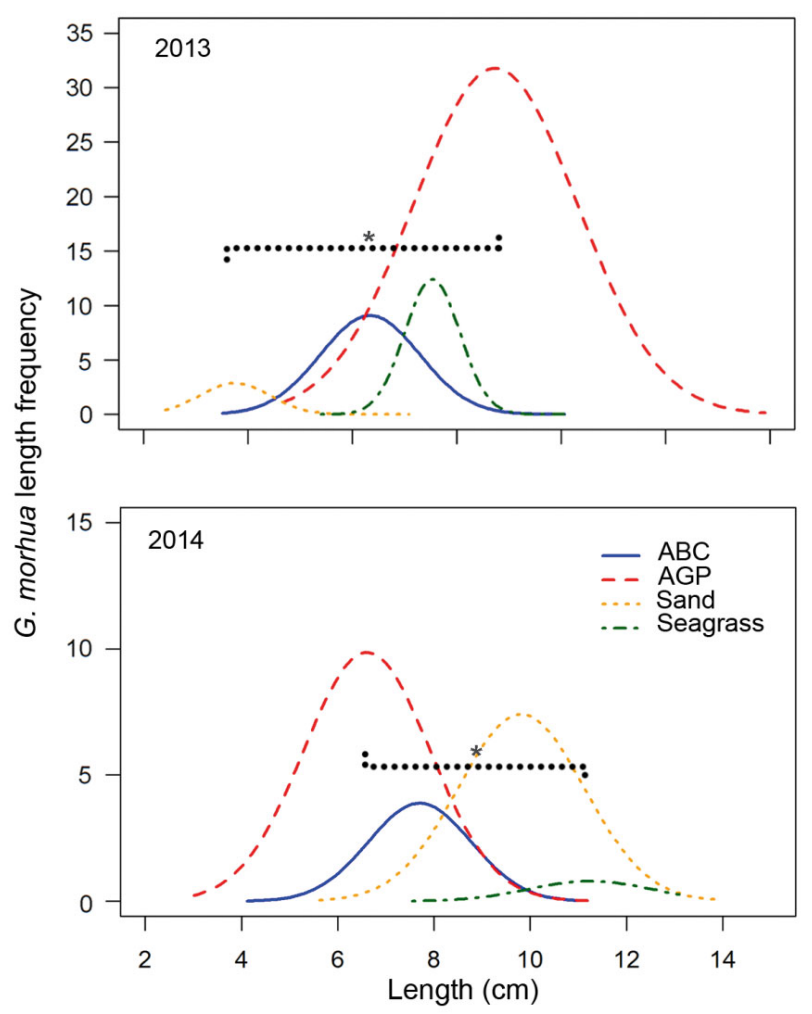

Fig. 6. Length-frequency distributions by substratum for Gadus morhua during 2013 and 2014. Year 2013 illustrates that G. morhua were significantly larger over algal-gravelpebble (AGP) than sand. During year 2014 G. morhua was significantly larger over seagrass than AGP. ABC refers to algal-boulder-cobble. Dotted horizontal lines with * refer to Tukey test $p$-value significance $(p<0.05)$

During field season 2013, a significant increase in length was observed $(\mathrm{l}=-15.56, \mathrm{df}=4, \mathrm{p}<0.05$; Table 4). During field season 2014, an increase in length with increasing depth was observed $(1=$ $-188.29, \mathrm{df}=3, \mathrm{p}<0.01$; Table 4).

\section{DISCUSSION}

There is a paucity of data on the habitat requirements of commercially important gadoids (Gadus morhua, Melanogrammus aeglefinus and Merlangius merlangus) within Eastern Atlantic waters. Our study provides information on the relationship between juvenile gadoid habitat variables from SBRUV field observations during daylight hours. A variety of habitat variables (5 substratum types, depth, wave fetch and Shannon-Wiener entropy) affected the distribution of these gadoids, demonstrating the importance of exploring abiotic and biotic factors that affect the distribution of species. It was observed that 
Table 4. Gadoid age-0 $(<15 \mathrm{~cm})$ length measurements and ontogenetic shift changes. na: not applicable

\begin{tabular}{|c|c|c|c|c|c|c|}
\hline Species & Year & $\begin{array}{l}\text { Number of length } \\
\text { measurements }\end{array}$ & $\begin{array}{l}\text { Mean length } \\
(\mathrm{cm}) \pm \mathrm{SE}\end{array}$ & $\begin{array}{l}\text { Minimum size } \\
\text { observed }(\mathrm{cm})\end{array}$ & $\begin{array}{l}\text { Length increase } \\
\text { significance }\end{array}$ & $\begin{array}{c}\text { Ontogenetic } \\
\text { shift significance }\end{array}$ \\
\hline \multirow[t]{2}{*}{ Gadus morhua } & 2013 & 123 & $7.4 \pm 0.2$ & 2.4 & $<0.001$ & $\begin{array}{c}\text { Shannon }<0.05 \\
\text { Substratum type }<0.05\end{array}$ \\
\hline & 2014 & 96 & $8.3 \pm 0.2$ & 3.0 & $<0.001$ & Substratum type $<0.05$ \\
\hline Melanogrammus & 2013 & 50 & $12.3 \pm 0.2$ & 7.6 & $<0.001$ & na \\
\hline aeglefinus & 2014 & 131 & $10.6 \pm 0.1$ & 6.7 & $<0.001$ & $\begin{array}{c}\text { Depth }<0.001 \\
\text { Wave fetch }<0.05\end{array}$ \\
\hline Merlangius & 2013 & 9 & $10.7 \pm 0.7$ & 8.3 & $<0.05$ & na \\
\hline merlangus & 2014 & 83 & $11.3 \pm 0.2$ & 6.3 & $>0.05$ & Depth $<0.01$ \\
\hline
\end{tabular}

the niche occupation of $G$. morhua was distinct from that of $M$. aeglefinus and $M$. merlangus. Furthermore ontogenetic shifts in the distribution of age-0 individuals were observed for a size range of $3-15 \mathrm{~cm}$.

Over both years of data collection, a greater relative abundance of $G$. morhua was observed over the AGP substratum type, with no individuals observed over mud and the fewest individuals observed over sand. These results support previous observations collected by stereo-video SCUBA transects (Elliott et al. 2016a). It is likely that fewer G. morhua were observed over seagrass areas due to the patchy, low density and small area (less than $1 \mathrm{~km}^{2}$ ) of seagrass (Jackson et al. 2001, Gorman et al. 2009, McCloskey \& Unsworth 2015) around South Arran (Elliott et al. 2016a). Fewer G. morhua may have been observed over ABC substrata as other potential predatory fish were observed around these areas e.g. age-1+ pollack Pollachius pollachius and saithe Pollachius virens. Similar laboratory results were observed by Gotceitas \& Brown (1993), where in the absence of predators, juvenile G. morhua were observed over gravel-pebble; however, in the presence of predators, they hid in the interstitial spaces of cobble. Much of the gravel where the SBRUV deployments took place around South Arran contained maerl. Maerl is thought to contribute to higher species diversity and heterogeneity and may be of importance to juvenile G. morhua (Hall-Spencer et al. 2003, Kamenos 2004).

During data collection period 2014, where significantly fewer G. morhua were observed, its relative abundance was reduced over all substrata apart from AGP where the $G$. morhua relative abundance remained more constant. This could be evidence of selection of AGP, with density-dependent dispersal to other substrata at higher population densities. This indicates that this substratum could be an important seabed type for juvenile G. morhua (Morris 1989,
2003, Swain \& Wade 1993). Lough (2010) also indicated that limited gravel areas may inhibit the survival of juvenile G. morhua. Juvenile G. morhua density-dependent substrata association was likewise observed by Laurel et al. (2004), who found that the abundance of $G$. morhua was consistently high over seagrass areas and more variable in sand.

Over the period of data collection, ontogenetic shifts in substratum association were observed. An increase in age-0 G. morhua relative abundance was observed over more structurally rugose substrata relative to their size. Keats \& Steele (1992), Laurel et al. (2007) and Tupper \& Boutilier (1995b) also observed ontogenetic shifts to more rugose substrata with increased size. Older (age-1+) and larger gadoids have, however, been observed to move into deeper, less rugose substrata with size (Cote et al. 2008, 2013, Munsch et al. 2016). Ontogenetic shifts within the size range observed highlights the importance of substrata of sufficient rugosity relative to the size of the individual and that multiple substratum types may be needed by the same species (Nagelkerken et al. 2013, Elliott et al. 2016b). Differences between years (2013 and 2014) may be due to on average larger individuals recorded in 2014 than 2013. In addition, in 2014, sampling took place at a larger range of depths than in 2013.

Although previous research has suggested that $M$. aeglefinus and $M$. merlangus do not seem to have a particular nursery grounds (Hislop 1996), significant substratum associations were observed. In contrast to G. morhua, higher relative abundances of both $M$. aeglefinus and $M$. merlangus were observed over sand followed by mud, with the fewest individuals observed over ABC substrata. Higher relative abundance over sand was also observed for both years of data collection for both species, indicating a selection for this substratum type. These results match laboratory and field studies undertaken with $M$. merlangus 
and M. aeglefinus (Auster et al. 2001, Atkinson et al. 2004). M. aeglefinus and M. merlangus also demonstrated ontogenetic shifts to deeper waters with increasing size. Such results demonstrate that measures to protect juveniles must be tailored to the species and life-history stages under consideration, and that there may not be general rules that apply evenly within groups of closely related fish (Nagelkerken et al. 2013).

Similarities in substratum association between $M$. aeglefinus and $M$. merlangus may be because, on average, $M$. aeglefinus and $M$. merlangus were similar in size, and individuals of both species were larger than G. morhua. Such size-related behaviour may reduce agonistic interactions, such as competition for resources between individuals and/or predation from larger individuals (Keats \& Steele 1992, Cote et al. 2008, Bastrikin et al. 2014). Speciesspecific segregation potentially reduces predation (Myers \& Cadigan 1993, Fromentin et al. 1997) and minimises competition, most likely as a result of different resource needs (Fromentin et al. 1997, Bastrikin et al. 2014).

The relative abundances of G. morhua and $M$. merlangus were positively correlated with ShannonWiener diversity entropy. This indicates that $G$. morhua and M. merlangus are found in higher relative abundance when epibenthic and demersal fauna composition is more even (where an increased ratio of the number of species relative to the total number of individuals is observed) (Hill 1973, Jost 2010). Maintaining species biological diversity is a well-known mechanism for maintaining the ecosystem services on which we depend (Worm et al. 2006, Beaumont et al. 2008).

Growth rates are also used as an indicator for the quality of a habitat (Gibson 1994, Searcy et al. 2007, Elliott et al. 2016b). This is particularly relevant in the case of G. morhua, where an increase in growth was correlated with an increase in epibenthic and demersal fauna diversity. More diverse areas can be assumed to represent higher-quality habitats. Declines in species diversity are largely caused by anthropogenic impacts such as exploitation, physical damage to substrata and pollution (Thrush \& Dayton 2002, Lotze 2006, Worm et al. 2006).

Much of the maerl found around South Arran is degraded as a result of historic dredging activity (Thurstan \& Roberts 2010). Shallower gravel-type substrata containing maerl, where G. morhua were found in greater relative abundance, could be more vulnerable to dredging activities that take place in these shallower areas (Collie et al. 2000, Kaiser et al.
2006). Protecting more biodiverse areas may support the survival of commercial fish (Worm et al. 2006, Beaumont et al. 2008).

Wave exposure has previously been identified as having a strong influence on the local distribution of coastal species (Burrows et al. 2008, Burrows 2012). For all 3 gadoids, a negative relationship between their relative abundance and wave fetch was observed. Fromentin et al. (1997) also observed higher abundances of $G$. morhua and $M$. merlangus in more sheltered areas within fjords as opposed to more exposed areas outside fjords. These results differ from the results of Lekve et al (2006), who found an increased abundance of G. morhua in more exposed areas. This is another example of the variability in natural history between G. morhua across its range.

Few studies have been undertaken using SBRUV as a mechanism to collect fisheries-independent data in the Europe. The findings within this study linking gadoid relative abundance to their habitats using SBRUV deployments within UK coastal waters have relevance across the region. With the increasing number of spatial closures being designated within European waters, SBRUV surveys could be used as a fisheries and marine protected area (MPA) monitoring method in a variety of conditions and seabed types, supporting more ecosystem-based management.

In conclusion, this study demonstrates the importance of taking into consideration a range of habitat variables to better understand demersal fish distribution. The link between epibenthic and demersal species diversity has significant management implications since insufficient good-quality habitat may be causing recruitment bottlenecks due to the carrying capacity of the environment (Svåsand et al. 2000). This has MPA and Marine Strategy Framework Directive (MSFD, 2008/56/EC) management and monitoring implications given that the descriptors linking together biodiversity (D1), seafloor integrity (D6) and commercially exploited fish (D3) indicators have not yet been addressed. We recommend linking commercially exploited fish during critical life phases to habitat variables to support the recovery of depleted fish stocks and implement more ecosystem-based management. By understanding the range of conditions suitable to gadoid species, adequate protection measures can be implemented to try to recover stocks through improved habitat quality.

Acknowledgements. Thanks to B. Allan, C. Willmott and J. Clarke for support in data collection and H. Wood, R. Cheshire and Millport Field Studies Council for the boat 
support for data collection. Thanks to B. McLaren for letting us use his swimming pool on Arran for SBRUV calibrations and to the University of Glasgow Spatial Analysis group (particularly P. Johnson and G. Hopcraft) for statistical support. We are also grateful to the anonymous reviewers for their valuable comments. We also thank Marine Scotland (Clyde 2020), Scottish Natural Heritage and the ClimateXChange and Natural Environment Research Council Facility for Scientific Diving (Grant NFSD/13/01) for student support, without which the collection of the data would not have been possible.

\section{LITERATURE CITED}

Able KW (1999) Measures of juvenile fish habitat quality: examples from a National Estuarine Research Reserve. In: Beneka LR (ed) Fish habitat: essential fish habitat and habitat rehabilitation. American Fisheries Society, Symp 22, Bethesda, MD, p 134-147

Anderson M, Gorley R, Clarke K (2008) PERMANOVA+ for PRIMER: guide to software and statistical methods. PRIMER-E, Plymouth

Atkinson CJL, Bergmann M, Kaiser MJ (2004) Habitat selection in whiting. J Fish Biol 64:788-793

Auster PJ, Joy K, Valentine PC (2001) Fish species and community distributions as proxies for seafloor habitat distributions: the Stellwagen Bank National Marine Sanctuary example (Northwest Atlantic, Gulf of Maine). Environ Biol Fishes 60:331-346

Bastrikin DK, Gallego A, Millar CP, Priede IG, Jones EG (2014) Settlement length and temporal settlement patterns of juvenile cod (Gadus morhua), haddock (Melanogrammus aeglefinus), and whiting (Merlangius merlangus) in a northern North Sea coastal nursery area. ICES J Mar Sci 71:2101-2113

* Beaumont NJ, Austen MC, Mangi SC, Townsend M (2008) Economic valuation for the conservation of marine biodiversity. Mar Pollut Bull 56:386-396

Beck MW, Heck KL, Able LW, Childers DL and others (2001) The identification, conservation, and management of estuarine and marine nurseries for fish and invertebrates. Bioscience 51:633-641

Bernard ATF, Götz A (2012) Bait increases the precision in count data from remote underwater video for most subtidal reef fish in the warm-temperate Agulhas bioregion. Mar Ecol Prog Ser 471:235-252

Bertelli CM, Unsworth RKF (2014) Protecting the hand that feeds us: seagrass (Zostera marina) serves as commercial juvenile fish habitat. Mar Pollut Bull 83:425-429

Bolker BM, Brooks ME, Clark CJ, Geange SW, Poulsen JR, Stevens MHH, White JSS (2009) Generalized linear mixed models: a practical guide for ecology and evolution. Trends Ecol Evol 24:127-135

Burrows MT (2012) Influences of wave fetch, tidal flow and ocean on subtidal rocky communities. Mar Ecol Prog Ser 445:193-207

Burrows MT, Harvey R, Robb L (2008) Wave exposure indices from digital coastlines and the prediction of rocky shore community structure. Mar Ecol Prog Ser 353:1-12

Cappo M, Harvey ES, Shortis M (2006) Counting and measuring fish with baited video techniques - an overview. In: Lyle JM, Furlani DM, Buxton CD (eds) Cutting-edge technologies in fish and fisheries science. Australian Society for Fish Biology, Hobart, p 101-114
Clarke KR, Green RH (1988) Statistical design and analysis for a 'biological effects' study. Mar Ecol Prog Ser 46: 213-226

Clarke KR, Warwick R (2001) Change in marine communities: an approach to statistical analysis and interpretation, 2nd edn. PRIMER-E, Plymouth, p 1-144

* Collie JS, Hall SJ, Kaiser MJ, Poiner IR (2000) A quantitative analysis of fishing impacts shelf-sea benthos. J Anim Ecol 69:785-798

Connor DW, Allen JH, Golding N, Kerry L, Lieberknecht LM, Northen KO, Reker JB (2004) The marine habitat classification for Britain and Ireland. Version 04.05. JNCC, Peterborough, http://jncc.defra.gov.uk/marinehabi tatclassification (accessed 12 November 2015)

Cote D, Ollerhead LMN, Scruton DA, McKinley RS (2003) Microhabitat use of juvenile Atlantic cod in a coastal area of Newfoundland determined by 2D telemetry. Mar Ecol Prog Ser 265:227-234

Cote D, Gregory RS, Stewart HMJ (2008) Size-selective predation by river otter (Lontra canadensis) improves refuge properties of shallow coastal marine nursery habitats. Can J Zool 86:1324-1328

Cote D, Gregory RS, Morris CJ, Newton BH, Schneider DC (2013) Elevated habitat quality reduces variance in fish community composition. J Exp Mar Biol Ecol 440:22-28

* Deter J, Descamp P, Boissery P, Ballesta L, Holon F (2012) A rapid photographic method detects depth gradient in coralligenous assemblages. J Exp Mar Biol Ecol 418-419: 75-82

* Dunlop KM, Marian Scott E, Parsons D, Bailey DM (2015) Do agonistic behaviours bias baited remote underwater video surveys of fish? Mar Ecol 36:810-818

* Elliott SAM, Ahti PA, Heath MR, Turrell WR, Bailey DM (2016a) An assessment of juvenile Gadus morhua distribution and growth using diver operated stereo-video surveys. J Fish Biol 89:1190-1207

Elliott SAM, Milligan RJ, Heath MR, Turrell WR, Bailey DM (2016b) Disentangling habitat concepts for demersal marine fish management. Oceanogr Mar Biol Annu Rev 54:171-181

FFernandes PG, Cook RM (2013) Reversal of fish stock decline in the Northeast Atlantic. Curr Biol 23:1432-1437

Fitzpatrick BM, Harvey ES, Heyward AJ, Twiggs EJ, Colquhoun J (2012) Habitat specialization in tropical continental shelf demersal fish assemblages. PLOS ONE 7:e39634

*FFromentin JM, Stenseth NC, Gjøsæter J, Bjørnstad ON, Falck W, Johannessen T (1997) Spatial patterns of the temporal dynamics of three gadoid species along the Norwegian Skagerrak coast. Mar Ecol Prog Ser 155: 209-222

Gibson RN (1994) Impact of habitat quality and quantity on the recruitment of juvenile flatfishes. Neth J Sea Res 32: 191-206

FGibson RN, Robb L, Burrows MT, Ansell AD (1996) Tidal, diel and longer term changes in the distribution of fishes on a Scottish sandy beach. Mar Ecol Prog Ser 130:1-17

*Gorman AM, Gregory RS, Schneider DC (2009) Eelgrass patch size and proximity to the patch edge affect predation risk of recently settled age 0 cod (Gadus). J Exp Mar Biol Ecol 371:1-9

Gotceitas V, Brown JA (1993) Substrate selection by juvenile Atlantic cod (Gadus morhua): effects of predation risk. Oecologia 93:31-37

* Gotceitas V, Fraser S, Brown JA (1995) Habitat use by juve- 
nile Atlantic cod (Gadus morhua) in the presence of an actively foraging and non-foraging predator. Mar Biol 123:421-430

Gratwicke B, Speight MR (2005) The relationship between fish species richness, abundance and habitat complexity in a range of shallow tropical marine habitats. J Fish Biol 66:650-667

* Gregory RS, Anderson JL (1997) Substrate selection and use of protective cover by juvenile Atlantic cod Gadus morhua in inshore waters of Newfoundland. Mar Ecol Prog Ser 146:9-20

* Hall-Spencer JM, Grall J, Moore PG, Atkinson RJ (2003) Bivalve fishing and maerl-bed conservation in France and the UK-retrospect and prospect. Aquat Conserv 13: S33-S41

Harvey ES, Shortis MR (1995) A system for stereo-video measurement of sub-tidal organisms. Mar Technol Soc J 29:10-22

Harvey ES, Shortis MR (1998) Calibration stability of an underwater stereo video system: implications for measurement accuracy and precision. Mar Technol Soc J 32: $3-17$

* Harvey ES, Fletcher D, Shortis MR (2002) Estimation of reef fish length by divers and by stereo-video. A first comparison of the accuracy and precision in the field on living fish under operational conditions. Fish Res 57:255-265

* Harvey ES, Cappo M, Butler JJ, Hall N, Kendrick GA (2007) Bait attraction affects the performance of remote underwater video stations in assessment of demersal fish community structure. Mar Ecol Prog Ser 350:245-254

Heath MR, Speirs DC (2012) Changes in species diversity and size composition in the Firth of Clyde demersal fish community (1927-2009). Proc R Soc B 279:543-552

Hill MO (1973) Diversity and evenness: a unifying notation and its consequences. Ecology 54:427-432

KHislop JRG (1996) Changes in North Sea gadoid stocks. ICES J Mar Sci 53:1146-1156

Holmes SJ, Millar CP, Fryer RJ, Wright PJ (2014) Gadoid dynamics: differing perceptions when contrasting stock vs. population trends and its implications to management. ICES J Mar Sci 71:1433-1442

Hothorn T, Bretz F, Westfall P (2008) Simultaneous inference in general parametric models. Biom J 50:346-363

International Council for the Exploration of the Sea (ICES) (2016a) Cod (Gadus morhua) in division VIa (West of Scotland). ICES, Copenhagen. www.ices.dk/sites/pub/ Publication\%20Reports/Advice/2015/2015/cod-scow.pdf (accessed 3 January 2016)

International Council for the Exploration of the Sea (ICES) (2016b) Haddock (Melanogrammus aeglefinus) in Subarea 4 and Divisions 6a and 3a West (North Sea, West of Scotland, Skagerrak). ICES, Copenhagen. www.ices.dk/ sites/pub/Publication \% 20Reports/Advice/2016/2016/ had-346a.pdf (accessed 3 January 2016)

International Council for the Exploration of the Sea (ICES) (2016c) Whiting (Merlangius merlangus) in Division 6a (West of Scotland). ICES, Copenhagen. www.ices.dk/ sites/pub/Publication \%20Reports/Advice/2016/2016/ whg-scow.pdf (accessed 3 January 2016)

Jackson EL, Rowden AA, Atrill AJ, Bossey SJ, Jones MB (2001) The importance of seagrass beds as a habitat for fishery species. Oceanogr Mar Biol Annu Rev 39: 269-305

Jost L (2010) The relation between evenness and diversity. Diversity 2:207-232
Kaiser MJ, Clarke KR, Hinz H, Austen MCV, Somerfield PJ, Karakassis I (2006) Global analysis of response and recovery of benthic biota to fishing. Mar Ecol Prog Ser 311:1-14

Kamenos NA (2004) Small-scale distribution of juvenile gadoids in shallow inshore waters: What role does maerl play? ICES J Mar Sci 61:422-429

KKamenos NA, Moore PG, Hall-Spencer JM (2003) Substratum heterogeneity of dredged vs un-dredged maerl grounds. J Mar Biol Assoc UK 83:411-413

* Keats DW, Steele DH (1992) Diurnal feeding of juvenile cod (Gadus morhua) which migrate into shallow water at night in eastern Newfoundland. J Northwest Atl Fish Sci 13:7-14

Kohler KE, Gill SM (2006) Coral Point Count with Excel extensions (CPCe): a Visual Basic program for the determination of coral and substrate coverage using random point count methodology. Comput Geosci 32:1259-1269

Kovalenko KE, Thomaz SM, Warfe DM (2012) Habitat complexity: approaches and future directions. Hydrobiologia 685:1-17

*Laurel BJ, Gregory RS, Brown JA, Hancock JK, Schneider DC (2004) Behavioural consequences of density-dependent habitat use in juvenile cod Gadus morhua and G. ogac: the role of movement and aggregation. Mar Ecol Prog Ser 272:257-270

พ Laurel BJ, Stoner A, Ryer CH, Hurst T, Abookire A (2007) Comparative habitat associations in juvenile Pacific cod and other gadids using seines, baited cameras and laboratory techniques. J Exp Mar Biol Ecol 351:42-55

* Laurel BJ, Knoth BA, Ryer CH (2016) Growth, mortality, and recruitment signals in age-0 gadids settling in coastal Gulf of Alaska. ICES J Mar Sci 73:2227-2237

* Lekve K, Enersen K, Enersen SE, Gjosaeter J, Stenseth NC (2006) Interannual variability in abundance and length of young coastal cod in the subtidal zone. J Fish Biol 68: 734-746

* Lima SL, Dill LM (1990) Behavioral decisions made under the risk of predation: a review and prospectus. Can J Zool 68:619-640

* Lotze HK (2006) Depletion, degradation, and recovery potential of estuaries and coastal seas. Science 312: 1806-1809

Lough RG (2010) Juvenile cod (Gadus morhua) mortality and the importance of bottom sediment type to recruitment on Georges Bank. Fish Oceanogr 19:159-181

Lowry M, Folpp H, Gregson M, Suthers I (2012) Comparison of baited remote underwater video (BRUV) and underwater visual census (UVC) for assessment of artificial reefs in estuaries. J Exp Mar Biol Ecol 416-417:243-253

*McCloskey RM, Unsworth RKF (2015) Decreasing seagrass density negatively influences associated fauna. PeerJ 3: e1053

* Morris DW (2003) Toward an ecological synthesis: a case for habitat selection. Oecologia 136:1-13

* Munsch SH, Cordell JR, Toft JD (2016) Fine-scale habitat use and behavior of a nearshore fish community: nursery functions, predation avoidance, and spatiotemporal habitat partitioning. Mar Ecol Prog Ser 557:1-15

* Myers RA, Cadigan NG (1993) Density-dependent juvenile mortality in marine demersal fish. Can J Fish Aquat Sci 50:1576-1590

Nagelkerken I, Sheaves M, Baker R, Connolly RM (2013) The seascape nursery: a novel spatial approach to identify and manage nurseries for coastal marine fauna. Fish Fish 16:1-10 
Olsen EM, Moland E (2011) Fitness landscape of Atlantic cod shaped by harvest selection and natural selection. Evol Ecol 25:695-710

Priede IG, Bagley PM, Smith A, Creasey S, Merrett NR (1994) Scavenging deep demersal fishes of the Porcupine Seabight, north-east Atlantic: observations by baited camera, trap and trawl. J Mar Biol Assoc UK 74:481-498

Searcy SP, Eggleston DB, Hare JA (2007) Is growth a reliable indicator of habitat quality and essential fish habitat for a juvenile estuarine fish? Can J Fish Aquat Sci 64: 681-691

Seitz RD, Wennhage H, Bergström U, Lipcius RN, Ysebaert $\mathrm{T}$ (2014) Ecological value of coastal habitats for commercially and ecologically important species. ICES J Mar Sci 71:648-665

Svåsand $T$, Kristiansen $T$, Pedersen $T$, Salvanes AV, Engelsen R, Naevdal G, Nødtvedt M (2000) The enhancement of cod stocks. Fish Fish 1:173-205

Swain DP, Wade EJ (1993) Density-dependent geographic distribution of Atlantic cod (Gadus morhua) in the southern Gulf of St. Lawrence. Can J Fish Aquat Sci 50:725-733

* Thrush SF, Dayton PK (2002) Disturbance to marine benthic habitats by trawling and dredging: implications for marine biodiversity. Annu Rev Ecol Syst 33:449-473

Thurstan RH, Roberts CM (2010) Ecological meltdown in the Firth of Clyde, Scotland: two centuries of change in a coastal marine ecosystem. PLOS ONE 5:e11767

Tupper M, Boutilier RG (1995a) Effects of habitat on settlement, growth, and postsettlement survival of At-

Editorial responsibility: Kenneth Sherman,

Narragansett, Rhode Island, USA lantic cod Gadus morhua. Can J Fish Aquat Sci 52: 1834-1841

Tupper M, Boutilier RG (1995b) Size and priority at settlement determine growth and competitive success of newly settled Atlantic cod. Mar Ecol Prog Ser 118:295-300

* Unsworth RKF, Peters JR, McCloskey RM, Hinder SL (2014) Optimising stereo baited underwater video for sampling fish and invertebrates in temperate coastal habitats. Estuar Coast Shelf Sci 150:281-287

* Vasconcelos RP, Eggleston DB, Le Pape O, Tulp I (2014) Patterns and processes of habitat-specific demographic variability in exploited marine species. ICES J Mar Sci 71: 638-647

Watson DL, Harvey ES, Anderson MJ, Kendrick GA (2005) A comparison of temperate reef fish assemblages recorded by three underwater stereo-video techniques. Mar Biol 148:415-425

Wentworth CK (1922) A scale of grade and class terms for clastic sediments. J Geol 30:377-392

* Worm B, Barbier EB, Beaumont N, Duffy JE and others (2006) Impacts of biodiversity loss on ocean ecosystem services. Science 314:787-790

*Wright PJ, Tobin D, Gibb FM, Gibb IM (2010) Assessing nursery contribution to recruitment: relevance of closed areas to haddock Melanogrammus aeglefinus. Mar Ecol Prog Ser 400:221-232

* Zuur AF, Leno EN, Elphick CS (2010) A protocol for data exploration to avoid common statistical problems. Methods Ecol Evol 1:3-14

Submitted: July 27, 2016; Accepted: January 25, 2017

Proofs received from author(s): March 6, 2017 